\title{
Detection of an unusually large hydrothermal event plume above the slow-spreading Carlsberg Ridge: NW Indian Ocean
}

\author{
Bramley J. Murton, ${ }^{1}$ Edward T. Baker, ${ }^{2}$ Carla M. Sands, ${ }^{1}$ and Christopher R. German ${ }^{3}$ \\ Received 14 February 2006; revised 20 April 2006; accepted 24 April 2006; published 31 May 2006.
}

[1] About 90\% of Earth's volcanism occurs along the global mid-ocean ridge system. Here, sporadic volcanic and tectonic activity is thought to cause cataclysmic release of hydrothermal fluids, forming event plumes. Each plume often contains as much hydrothermal effluent and heat as chronic hydrothermal venting from a typical vent site discharges during a year. To date, only a few event plumes have been detected, and only above intermediate-rate spreading ridges in the Pacific. Here, we report the first evidence for an unusually large event plume that originated from the slow-spreading ( $3 \mathrm{~cm} / \mathrm{yr}$ full-rate) Carlsberg Ridge in the NW Indian Ocean. At $70 \mathrm{~km}$ long, up to $4540 \mathrm{~km}^{3}$ in volume and with up to $24 \times 10^{16} \mathrm{~J}$ of excess heat, this event plume was substantially larger than previous ones and demonstrates that dispersion of hydrothermal heat and biological products from slow spreading ridges may be more significant and effective than hitherto imagined. Citation: Murton, B. J., E. T. Baker, C. M. Sands, and C. R. German (2006), Detection of an unusually large hydrothermal event plume above the slow-spreading Carlsberg Ridge: NW Indian Ocean, Geophys. Res. Lett., 33, L10608, doi:10.1029/ 2006GL026048.

\section{Introduction}

[2] Submarine hydrothermal activity is a major conduit for transferring heat from the Earth's interior, and thus plays an important role in global ocean heat and chemical budgets [Baker and German, 2004]. Some of the most spectacular features of this activity are event plumes (EP's): boluses of tens of cubic kilometers of warm and turbid water, apparently triggered by seafloor volcanic and tectonic activity [Baker et al., 1987]. While individual EP's contain hundreds of times more heat than steady-state (i.e., chronic) hydrothermal plumes, they have been observed only rarely and exclusively above intermediate spreading-rate $(5.5-8 \mathrm{~cm} / \mathrm{yr}$ full-rate) mid-ocean ridges (MOR's) in the Pacific Ocean [Baker, 1998; Nojiri et al., 1989]. Hence their global significance remains uncertain. While a transient thermal event on the Mid-Atlantic Ridge was inferred from temperature excursions [Murton and Redbourn, 2000], the question remains how EP's are manifest at other spreading rates and, specifically, at slow spreading ridges (that constitute more than half the global MOR system). The significance of

\footnotetext{
${ }^{1}$ National Oceanography Centre Southampton, University of Southampton Waterfront Campus, Southampton, UK.

${ }^{2}$ Pacific Marine Environmental Laboratory, NOAA, Seattle, Washington, USA.

${ }^{3}$ Woods Hole Oceanographic Institution, Woods Hole, Massachusetts, USA.
}

Copyright 2006 by the American Geophysical Union. 0094-8276/06/2006GL026048\$05.00
EP's goes beyond mere novelty. They dissipate a greater proportion of heat compared to their dissolved chemical content than chronic high-temperature hydrothermal venting. Thus their occurrence at slow spreading ridges would extend this mode of hydrothermal circulation to a significantly greater proportion of the global MOR system. EP's may also provide the essential mechanism whereby large numbers of larvae of hydrothermal vent fauna can simultaneously escape the confining topography of slow spreading ridges to colonize distant, alternative sites.

\section{Results}

[3] In July 2003, CTD (Conductivity Temperature Depth) and MAPR (Miniature Autonomous Plume Recorder) casts were made over the Carlsberg Ridge, NW Indian Ocean. The instruments were inter-calibrated by deployment at the same station. Both types of instruments measured optical backscatter (OBS) and temperature, while salinity and water samples were acquired exclusively by CTD. In total, 36 vertical casts (including up and down profiles of up to $4 \mathrm{~km}$ apart) were made at 18 separate stations along the ridge axis. Sea conditions allowed occupation of only one full ocean depth CTD-rosette station, from which sixteen water samples were collected.

[4] OBS anomalies from 12 vertical profiles (Figure 1a) defined an exceptionally large, particle-rich plume (termed here: CR2003) overlying at least $70 \mathrm{~km}$ of the ridge crest between $61^{\circ} 30 \mathrm{E}, 5^{\circ} 41^{\prime} \mathrm{N}$ and $60^{\circ} 33^{\prime} \mathrm{E}, 6^{\circ} 20^{\prime} \mathrm{N}$ (Figure $1 \mathrm{~b}$ ). Where found (on 23-24th July, 2003) CR2003 appeared similar in all profiles: being 700-1000 $\mathrm{m}$ thick and with peaks in OBS at $2330 \mathrm{~m}, 2500 \mathrm{~m}, 2700 \mathrm{~m}$ and $2900 \mathrm{~m}$. Its top reached $2200 \mathrm{~m}$, some $1200-1400 \mathrm{~m}$ above the rift floor and well clear the axial walls. These observations indicated a continuous plume originating from a common source. Toward the northwest (profile WP6 at $60^{\circ} 56^{\prime} \mathrm{E}, 6^{\circ} 03^{\prime} \mathrm{E}$ ) both OBS and temperature increased steadily downward to the seafloor, indicating the origin of CR2003 from the crest of a $40 \mathrm{~km}$-long axial volcanic ridge (Figure 1c).

[5] Potential temperature $(\theta)$ and salinity $(S)$ data revealed $\theta / \mathrm{S}$ ratios within $\mathrm{CR} 2003$ that were distinctly different from the background water column (Figure 2). At a given potential density $\left(\sigma_{2500}\right)$, referenced to a depth of $2500 \mathrm{~m}, \mathrm{CR} 2003$ was both colder and less saline than background, a feature typical for neutrally buoyant hydrothermal plumes in the deep Atlantic and Indian oceans [Speer and Rona, 1989; Rudnicki and German, 2002]. Isohaline estimates of excess temperature $(\Delta \theta)$, calculated by deviations from the linear $\theta / \mathrm{S}$ of the background water column [McDougall, 1990; Thurnherr and Richards, 2001], correlated closely with increasing OBS and yielded a maximum excess temperature of $+0.07^{\circ} \mathrm{C}$ (Figure 2b). 


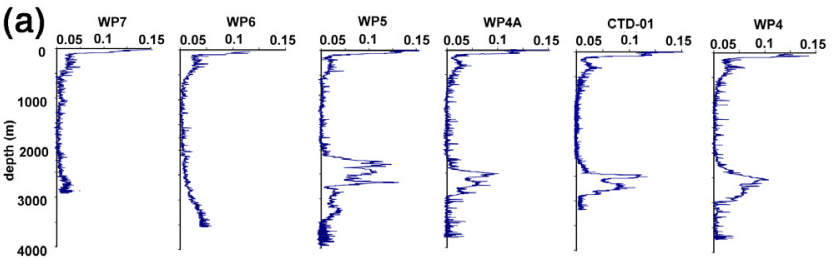

(b)

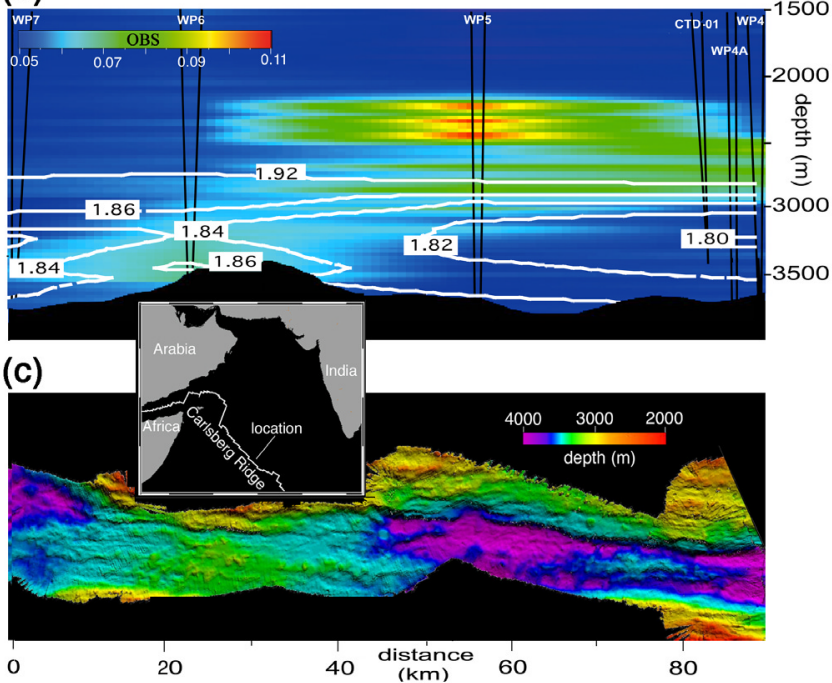

Figure 1. (a) Vertical profiles of optical backscatter (OBS) expressed as NTUs (nephelometric turbidity units) showing a common structure and depth for the particulate plume. (b) Colored 2D plot of OBS and in situ temperature (white contours annotated in ${ }^{\circ} \mathrm{C}$ ), with locations of up and down casts (black lines) made at each station (annotated), along $90 \mathrm{~km}$ of the crest of the Carlsberg Ridge, over a period of 43 hours. The profiles were collected using CTD (Conductivity Temperature Depth) and MAPR (Miniature Autonomous Plume Recorder) instruments. These recorded temperature, depth and optical backscattering anomalies. The black silhouette indicates the sea floor topography. (c) Multibeam swath bathymetry showing second order ridge segments forming basins floored by axial volcanic ridges and flanked by $800-1000 \mathrm{~m}$ high axial walls.

Concentrations of manganese and iron also correlated with increases in both $\Delta \theta$ and OBS throughout the vertical profile occupied by the CTD rosette (Figure 2c).

[6] The only known mechanism for injecting a bolus of water with excess temperature, depleted salinity, and elevated manganese and iron concentrations high above an MOR is hydrothermal activity. The excess iron alone indicates local provenance (iron readily oxidizes and settles after flocculating). Alternative origins - such as Red Sea outfall advected for over $1000 \mathrm{~km}$ to the Carlsberg Ridge would yield warm but salty water, without elevated concentrations of dissolved metals. Likewise resuspended pelagic sediment would lack both a salinity and temperature anomaly.

\section{Interpretation}

[7] While CR2003 had many characteristics typical of neutrally buoyant plumes from high-temperature hydrother- mal discharge [Baker et al., 1995], it also had some important differences, being: wider (e.g. $\sim 70 \mathrm{~km}$ compared with 5-15 km), arose higher (1000-1400 m vs. $150-250$ $\mathrm{m})$, and thicker $(700-1000 \mathrm{~m} v \mathrm{~s} .100-250 \mathrm{~m})$. In these respects it more closely resembled EP's of the type described from the Pacific Ocean [e.g., Baker et al., 1989], although the latter were a third smaller $(\sim 20 \mathrm{~km}$ in diameter).

[8] Diagnostically, EP's are distinguished from chronic hydrothermal plumes by a TDMn/heat ratio of $<0.15 \mathrm{nMol} / \mathrm{J}$ (compared with an average of 0.25), indicating higher rates of heat transfer for corresponding rates of chemical ex-

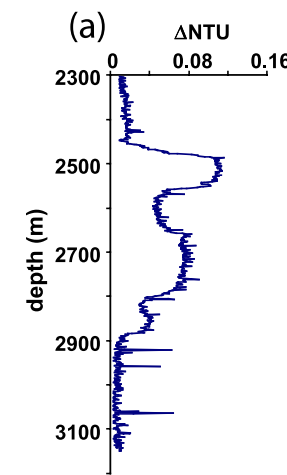

(d)

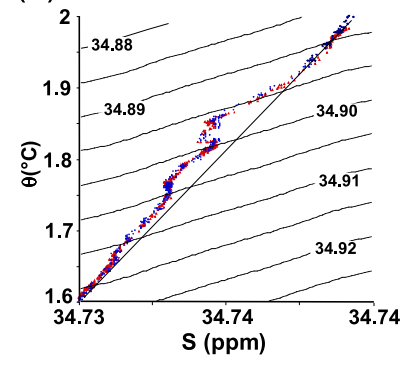

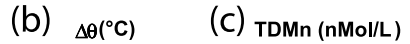

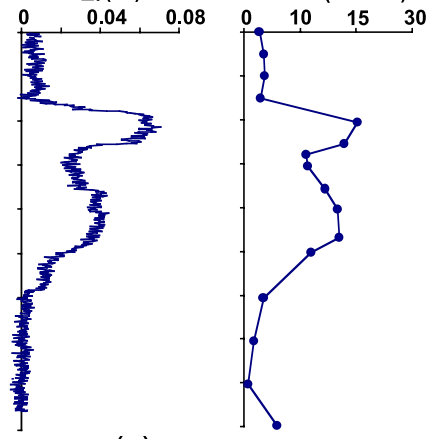

(e)

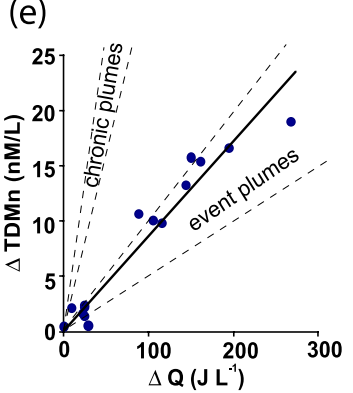

Figure 2. Vertical profiles determined at hydrographic station CTD-01 showing (a) the anomalies in optical backscatter $(\Delta N T U)$. (b) Excess temperature $(\Delta \theta)$ calculated from the deviation of $\theta$ from its bi-linear mixing relationship with S (e.g., Figure 2d) as expressed immediately above and below plume depth [Thurnherr and Richards, 2001]. Such isohaline estimates of $\Delta \theta$ assume purely geothermal heating and are subject to $\sim 40 \%$ error caused by uncertainties in the salinity of the discharged hydrothermal effluent and the variable entrainment of bottom water [Lavelle and Baker, 1994]. (c) Total dissolvable manganese (TDMn), analysed by graphite furnace atomic absorption spectroscopy following pre-concentration by complexation with dithiocarbamate and solvent extraction with chloroform [Bruland et al., 1979; Statham, 1985]. (d) Isopycnal contours of potential density (labeled as $\mathrm{g} \mathrm{L}^{-1} \mathrm{~m}^{-1}+1000$ ), mapped to a reference pressure of 250 bar, show water within CR2003 was less saline $(\mathrm{S})$ and of lower potential temperature $(\theta)$ than background water of similar density. (e) Excess total dissolvable manganese $(\Delta \mathrm{TDMn})$ correlates with excess heat $(\Delta \mathrm{Q})$ indicating a high temperature, hydrothermal source. $\Delta$ TDMn/heat in CR2003 falls within the field of known EP's and well below the field for hydrothermal plumes emanating from chronic 'black smokers' [Massoth et al., 1998]. 
Table 1. Comparison Between CR2003 and Other MOR Event Plumes ${ }^{\mathrm{a}}$

\begin{tabular}{|c|c|c|c|c|c|c|c|}
\hline Event Plume & MOR Location & Heat, $10^{15} \mathrm{~J}$ & Mn/Heat, nMol J ${ }^{-1}$ & $\mathrm{Fe} / \mathrm{Mn}$ & Size, $\mathrm{km}$ & Riseheight, $\mathrm{m}$ & Thickness, $\mathrm{m}$ \\
\hline $\mathrm{EP} 8 \mathrm{~A}^{\mathrm{b}}$ & SJdFR & 89 & $0.11 \pm 0.03$ & $7.6 \pm 2.1$ & 20 & 1000 & 600 \\
\hline$E P 87 A^{c}$ & SJdFR & 32 & $0.08 \pm 0.01$ & $1.8 \pm 0.3$ & 16 & 500 & 600 \\
\hline KAIYO $87^{\mathrm{d}}$ & NFB & ND & 0.031 & ND & ND & 900 & 500 \\
\hline EP93A $^{\mathrm{e}}$ & NJdFR & 4.1 & $0.14 \pm 0.08$ & $6.9 \pm 1.5$ & 10 & 1100 & 400 \\
\hline EP93B $^{\text {f }}$ & NJdFR & 10 & $0.16 \pm 0.01$ & $4.3 \pm 0.8$ & 5 & 1000 & 400 \\
\hline EP93C $C^{f}$ & NJdFR & 18 & $0.11 \pm 0.03$ & $4.5 \pm 1.1$ & 5 & 700 & 600 \\
\hline EP96A $^{\mathrm{g}}$ & GR & 21 & $0.11 \pm 0.02$ & $5.7 \pm 1.2$ & 12 & 700 & 600 \\
\hline EP96B $^{\mathrm{g}}$ & GR & 5.1 & $0.1 \pm 0.02$ & $7.4 \pm 0.9$ & 5 & 600 & 500 \\
\hline CR2003 & CR & $74-240$ & $0.08 \pm 0.02$ & $5.1 \pm 0.7$ & $>70$ & 1400 & $700-1000$ \\
\hline
\end{tabular}

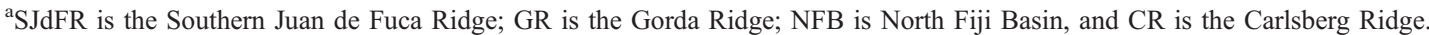

${ }^{\mathrm{b}}$ Baker et al. [1987], ${ }^{\mathrm{c}}$ Baker et al. [1989], ${ }^{\mathrm{d}}$ Nojiri et al. [1989], ${ }^{\mathrm{e}}$ Massoth et al. [1994], ${ }_{\mathrm{f}}$ Massoth et al. [1995], ${ }^{\mathrm{g}}$ Massoth et al. [1998].

change [Massoth et al., 1995, 1998]. The heat content per unit volume $(\mathrm{Q})$ is calculated from $\Delta \theta$ by:

$$
\mathrm{Q}=\rho \mathrm{C}_{\mathrm{p}} \Delta \theta_{\mathrm{i}}
$$

Where: $\mathrm{Q}$ is in Joules, $\rho$ is the density of seawater at an ambient pressure of 250 bars at $2^{\circ} \mathrm{C}$ (e.g. $\left.1029 \mathrm{~kg} \mathrm{~L}^{-1}\right), \mathrm{Cp}$ is the specific thermal capacity of seawater at $250 \mathrm{bars}$ $(4100 \mathrm{~J} / \mathrm{Kg})$, and $\Delta \theta_{\mathrm{i}}$ is the calculated excess temperature at depth interval i [Bischoff and Rosenbauer, 1985; Gill, 1982].

[9] Equation (1) yields a mean $\mathrm{Q}$ of $139 \mathrm{~J} / \mathrm{L}$ for CR2003, between $2450 \mathrm{~m}$ and $2900 \mathrm{~m}$, with a maximum of $284 \mathrm{~J} / \mathrm{L}$ occurring at $2500 \mathrm{~m}$, coincident with the largest OBS signal. Significantly, CR2003 had a TDMn/heat ratio of $0.08 \pm$ $0.03 \mathrm{nMol} / \mathrm{J}$, placing it well within the field of known EP's [Massoth et al., 1995, 1998] (Figure 2e).

[10] While CR2003 overlay at least $70 \mathrm{~km}$ of the Carlsberg Ridge crest, all previously observed EP's were axisymmetric and less than $20 \mathrm{~km}$ wide. Experimental and numerical simulations give an explanation for this limitation [Lavelle, 1995; Woods and Bush, 1999]: elongate EP's rapidly form a string of axisymmetric rotational eddies each with a radius, in deep-ocean conditions, of approximately 10 times the plume's rise-height. Assuming CR2003 comprised a series of quasi-merged eddies, with a length (L) greater than an individual eddy radius (R), its volume (V) can is approximated by:

$$
\mathrm{V}=\Sigma\left(\pi \mathrm{z} \mathrm{R}_{\mathrm{i}} \mathrm{L}_{\mathrm{i}} / 2\right)
$$

Where $\mathrm{z}$ is the thickness, $\mathrm{R}$ is the radius, $\mathrm{L}$ is the length of each layer between depth intervals (i), and the outer boundary of each layer is where $\Delta \theta_{\mathrm{I}}>0.001{ }^{\circ} \mathrm{C}$.

[11] And the volume for each depth interval (i) is approximated by:

$$
\mathrm{V}_{\mathrm{i}}=\pi \mathrm{z} \mathrm{R}_{\mathrm{i}} \mathrm{L}_{\mathrm{i}} / 2
$$

Equations (2) and (3) are used to derive a lower estimated volume for CR2003 of $\sim 1,500 \mathrm{~km}^{3}$. Alternatively, an upper estimate follows if we assume CR2003 had a normal axisymmetric shape. This is calculated by substituting $\mathrm{L} / 2$ for $\mathrm{R}$ in equations (2) and (3) above and yields $\sim 4,500 \mathrm{~km}^{3}$. From this, the total heat content $(\mathrm{H})$ of the plume is approximated by:

$$
\mathrm{H}=\Sigma \mathrm{Q}_{\mathrm{i}} \mathrm{V}_{\mathrm{i}}
$$

where $\mathrm{Q}_{\mathrm{i}}$ is the average heat content for the plume volume $\left(V_{i}\right)$ between each depth interval (i).
[12] In the absence of $\mathrm{S}$ and $\Delta \theta, \mathrm{Q}$ is inferred from its correlation with excess OBS $(\Delta \mathrm{n})$ :

$$
\mathrm{Q}=200 \Delta \mathrm{n},\left(\mathrm{r}^{2}=0.88\right)
$$

From equations (1) to (5), the heat content of CR2003 is estimated between $7.4 \times 10^{16} \mathrm{~J}$ and $2.4 \times 10^{17} \mathrm{~J}$. The propagated error in both cases is $\pm 40 \%$, largely as a result of uncertainty in $\Delta \theta$.

[13] These heat contents allow calculation of the equivalent volume of basaltic magma $\left(\mathrm{V}_{\mathrm{b}}\right)$ that has cooled from its liquid temperature to the ambient temperature of the bottom water:

$$
\mathrm{V}_{\mathrm{b}}=\mathrm{H} /\left[\rho_{\mathrm{m}}\left(\mathrm{Cp}_{\mathrm{m}} \Delta \mathrm{T}_{\mathrm{m}}+\mathrm{L}\right)+\rho_{\mathrm{b}}\left(\mathrm{Cp}_{\mathrm{b}} \Delta \mathrm{T}_{\mathrm{b}}\right)\right]
$$

where: $\mathrm{H}$ is the heat content of the plume, $\rho_{\mathrm{m}}, \mathrm{Cp}_{\mathrm{m}}$ and $\mathrm{L}$ are the density $\left(2700 \mathrm{~kg} \mathrm{~m}^{-3}\right)$, specific heat $\left(1000 \mathrm{~J} \mathrm{~kg}^{-1} \mathrm{C}^{-1}\right)$ and latent heat of crystallization $\left(4 \times 10^{5} \mathrm{~J} \mathrm{~kg}^{-1}\right)$ of basaltic magma at 8 wt. $\% \mathrm{MgO}$ respectively and $\left(\Delta \mathrm{T}_{\mathrm{m}}\right)$ is the temperature difference between eruption $\left(1200^{\circ} \mathrm{C}\right)$ and solidification $\left(1000^{\circ} \mathrm{C}\right) ; \rho_{\mathrm{b}}$ is the density $\left(3000 \mathrm{~kg} \mathrm{~m}^{-3}\right)$ and $\mathrm{Cp}_{\mathrm{b}}$ the specific thermal capacity $\left(1100 \mathrm{~J} \mathrm{~kg}^{-1} \mathrm{C}^{-1}\right)$ of the solid basalt and $\Delta \mathrm{T}_{\mathrm{b}}$ the temperature difference between solidification $\left(1000^{\circ} \mathrm{C}\right)$ and the bottom water $\left(2^{\circ} \mathrm{C}\right)$.

[14] Equation (6) yields an estimated volume of basaltic magma of between $1.7 \pm 0.7 \times 10^{7} \mathrm{~m}^{3}$ (i.e., $0.03 \mathrm{~km}^{3}$ ) and $5.5 \pm 2.2 \times 10^{7} \mathrm{~m}^{3}$ (i.e. $0.1 \mathrm{~km}^{3}$ ); equivalent to a $2 \mathrm{~m}$ thick circular flow of between 1.7 and $3 \mathrm{~km}$ in radius, or a dike $1 \mathrm{~m}$ wide by $2 \mathrm{~km}$ high and between 9 and $27 \mathrm{~km}$ long.

\section{Discussion}

[15] While the chemical and thermal similarity of CR2003 to previous EP's formed above intermediate spreading MOR's (Table 1) implies a common mode of origin, CR2003's unusually large size suggests EP formation is sensitive to spreading rate.

[16] Brittle failure of the shallow crust causing a sudden release of warm hydrothermal fluid [e.g., Cann and Strens, 1989] is unlikely to have generated CR2003 or other EP's, which are chemically distinct from high-temperature hydrothermal effluent (having lower metal/heat [Massoth et al., 1995] and helium/heat ratios [Lupton et al., 1999]). Assuming a mean temperature in layer $2 \mathrm{~A}$ of $50^{\circ} \mathrm{C}$ [Henstock et al., 1993] and a porosity of $15 \%$ [Jacobson, 1992], CR2003 would require between 3.5 and $13 \times 10^{8} \mathrm{~m}^{3}$ of warm $\left(50^{\circ} \mathrm{C}\right)$ fluid, released from between 2.8 and $8.6 \mathrm{~km}^{3}$ of 
rock. But it is unclear whether such a bolus of warm fluid would arise 1000 to $1400 \mathrm{~m}$ [Turner and Campbell, 1987; Lupton, 1995].

[17] Alternatively, Palmer and Ernst [1998] proposed a compelling model for EP formation by the eruption of pillow lavas, citing experiments that produced $\mathrm{Mn} / \mathrm{Heat}$ ratios, from quenching basalt, within the known range for EP's [Seyfried and Mottl, 1982]. The model also predicts EP magnitude to vary proportionally with eruption volume. The latter is thought to scale inversely with spreading rate [Perfit and Chadwick, 1999], probably as a result of the coupled thermal and mechanical properties of spreading ridges, where strain is proportional to opening stress multiplied by the height of a dike [Jacoby and Higgs, 1995]. Because dike height is thought to relate to the thickness of the brittle lid [Smith and Cann, 1993], a thicker lid on slow spreading ridges results in greater magma overpressure and less frequent but wider dikes feeding larger eruptive volumes. Thus the unusually large size of CR2003 may be a common feature of slow spreading ridges.

[18] The relationship between spreading rate and the magnitude of an EP may also play an important role in the biogeography and diversity of hydrothermal vent invertebrates. Gene flow between slow spreading MOR hydrothermal sites is thought to depend particularly on the ability of larvae to escape topographic and hydrographic barriers, such as deep axial valleys and fracture zones [Mullineaux and France, 1995; Van Dover et al., 2002; Tyler and Young, 2003]. This has been shown for the Mid-Atlantic Ridge where larval dispersion is strongly restricted by the deep and enclosing rift walls [Murton et al., 1999]. Yet as MOR topography becomes more rugged with decreasing spreading rate, a corresponding increase in eruption volume can trigger larger magnitude EP's (like CR2003), which entrain greater numbers of larvae and rise higher above the rift walls where they can be steered by currents flowing parallel to the underlying topography [Thurnherr and Richards, 2001]. Thus EP's might provide the essential mechanism for vent fauna to escape en mass, migrate and ultimately colonize widely separated hydrothermal vent sites along slow-spreading MOR's.

[19] Acknowledgments. We wish to thank the officers and crew of RRS Charles Darwin for their professional seamanship during cruise CD149. Also the anonymous reviewers whose comments greatly improved this contribution. This work was supported by the Natural Environment Research Council, UK; the National Oceanography Centre, Southampton (NOCS); the NOAA Vents Program; and is PMEL contribution 2905.

\section{References}

Baker, E. T. (1998), Patterns of event and chronic hydrothermal venting following a magmatic intrusion: New perspectives from the 1996 Gorda Ridge eruption, Deep Sea Res., Part II, 45, 2599-2618.

Baker, E. T., and C. R. German (2004), On the global distribution of hydrothermal vents, in Mid-Ocean Ridge Hydrothermal Interactions Between Lithosphere and Oceans, Geophys. Monogr. Ser., vol. 148, edited by C. G. German, J. Lin, and L. M. Parson, pp. 245-266, AGU, Washington, D. C.

Baker, E. T., G. J. Massoth, and R. A. Feely (1987), Cataclysmic hydrothermal venting on the Juan de Fuca Ridge, Nature, 329, 149151.

Baker, E. T., J. W. Lavelle, R. A. Feely, G. J. Massoth, S. L. Walker, and J. E. Lupton (1989), Episodic venting of hydrothermal fluids from the Juan de Fuca Ridge, J. Geophys. Res., 94, 9237-9250.

Baker, E. T., C. R. German, and H. Elderfield (1995), Hydrothermal plumes over spreading-center axes: Global distributions and geological inferences, in Seafloor Hydrothermal Systems: Physical, Chemical, Biologi- cal, and Geological Interactions, Geophys. Monogr. Ser., vol. 91, edited by S. E. Humphris et al., pp. 47-71, AGU, Washington, D. C.

Bischoff, J. L., and R. J. Rosenbauer (1985), An empirical equation of state for hydrothermal seawater $(3.2$ percent $\mathrm{NaCl}), A m$. J. Sci., 285, $725-763$.

Bruland, K. W., R. P. Franks, G. A. Knaur, and J. M. Martin (1979), Sampling and analytical methods for the determination of copper, cadmium, zinc and nickel at the nanogram per litre level in sea water, Anal. Chim. Acta, 105, 233-245.

Cann, J. R., and M. R. Strens (1989), Modeling periodic megaplume emission by black smoker systems, J. Geophys. Res., 94, 12,227$12,237$.

Jacobson, R. S. (1992), Impact of crustal evolution on changes of the seismic properties of the uppermost ocean crust, Rev. Geophys., 30, $23-42$.

Jacoby, W. R., and B. Higgs (1995), On the rifting dynamics of plate divergence and magma accumulation at oceanic ridge axes, Pure App. Geophys., 145, 505-521.

Gill, A. E. (1982), Atmosphere-Ocean Dynamics, 662 pp., Elsevier, New York.

Henstock, T. J., A. W. Woods, and R. S. White (1993), Accretion of oceanic crust by episodic sill intrusion, J. Geophys. Res., 98, 4143-4162.

Lavelle, J. W. (1995), The initial rise of a hydrothermal plume from a line segment source-Results from a three-dimensional numerical model, Geophys. Res. Lett., 22, 159-162.

Lavelle, J. W., and E. T. Baker (1994), A numerical study of local convection in the benthic ocean induced by episodic hydrothermal discharges, J. Geophys. Res., 99, 16,065-16,080.

Lupton, J. E. (1995), Hydrothermal plumes near and far field, in Seafloor Hydrothermal Systems Physical, Biological and Geophysical Interactions, Geophys. Monogr. Ser, vol. 91, edited by S. Humphries et al., pp. 317-346, AGU, Washington, D. C.

Lupton, J. E., E. T. Baker, and G. J. Massoth (1999), Helium, heat, and the generation of hydrothermal event plumes at mid-ocean ridges, Earth Planet. Sci. Lett., 171, 343-350.

Massoth, G. J., E. T. Baker, J. E. Lupton, R. A. Feely, D. A. Butterfield, K. L. Von Damm, K. K. Roe, and G. T. Lebon (1994), Temporal and spatial variability of hydrothermal manganese and iron at Cleft segment, Juan de Fuca Ridge, J. Geophys. Res., 99, 4905-4924.

Massoth, G. J., E. T. Baker, R. A. Feely, D. A. Butterfield, R. E. Embley, J. E. Lupton, R. E. Thomson, and G. A. Cannon (1995), Observations of manganese and iron at the CoAxial seafloor eruption site, Juan de Fuca Ridge, Geophys. Res. Lett., 22, 151-154.

Massoth, G. J., E. T. Baker, R. A. Feely, J. E. Lupton, R. W. Collier, J. F. Gendron, K. K. Roe, S. M. Maenner, and J. A. Resing (1998), Manganese and iron in hydrothermal plumes resulting from the 1996 Gorda Ridge Event, Deep Sea Res., Part II, 45, 2683-2712.

McDougall, T. J. (1990), Bulk properties of "hot smoker" plumes, Earth Planet. Sci. Lett., 99, 185-194.

Mullineaux, L. S., and S. C. France (1995), Dispersal mechanisms of deepsea hydrothermal vent fauna, in Seafloor Hydrothermal Systems: Physical, Chemical, Biological and Geological Interactions, Geophys. Monogr. Ser., vol. 91, edited by S. Humphries et al., pp. 408-424, AGU, Washington, D. C.

Murton, B. J., and L. J. Redbourn (2000), Oceanographic evidence for a transient geothermal event affecting the Mid-Atlantic Ridge, Geophys. Res. Lett., 27, 1507-1510.

Murton, B. J., L. J. Redbourn, C. R. German, and E. T. Baker (1999), Sources and fluxes of hydrothermal heat, chemicals and biology within a segment of the Mid-Atlantic Ridge, Earth Planet. Sci. Lett., 171, $301-$ 317.

Nojiri, Y., J. Ishibashi, T. Kawai, and H. Sakai (1989), Hydrothermal plumes along the North Fiji Basin spreading axis, Nature, 342, 667670.

Palmer, M. R., and G. G. J. Ernst (1998), Generation of hydrothermal megaplumes by cooling of pillow basalts at mid-ocean ridges, Nature, 393, 643-647.

Perfit, M. R., and W. W. Chadwick (1999), Magmatism at mid-ocean ridges: Constraints from volcanological and geochemical investigations, in Faulting and Magmatism at Mid-Ocean Ridges, Geophys. Monogr. Ser., vol. 106, edited by R. W. Buck et al., pp. 59-115, AGU, Washington, D. C.

Rudnicki, M. D., and C. R. German (2002), Temporal variability of the hydrothermal plume above the Kairei vent field, $25^{\circ} \mathrm{S}$, Central Indian Ridge, Geochem. Geophys. Geosyst., 3(2), 1010, doi:10.1029/ $2001 \mathrm{GC} 000240$.

Seyfried, W. E., Jr., and M. J. Mottl (1982), Hydrothermal alteration of basalt by seawater under seawater-dominated conditions, Geochim. Cosmochim. Acta, 46, 985-1002.

Smith, D. K., and J. R. Cann (1993), Building the crust at the Mid-Atlantic Ridge, Nature, 365, 707-715. 
Speer, K. G., and P. A. Rona (1989), A model of an Atlantic and Pacific hydrothermal plume, J. Geophys. Res., 94, 6213-6220.

Statham, P. J. (1985), The determination of dissolved manganese and cadmium in sea water at low nmol $\mathrm{L}^{-1}$ concentrations by chelation and extraction followed by electrothermal atomic absorption spectroscopy, Anal. Chim. Acta, 169, 149-158.

Thurnherr, A. M., and K. J. Richards (2001), Hydrography and high-temperature heat flux of the Rainbow hydrothermal site $\left(36^{\circ} 14^{\prime} \mathrm{N}\right.$, MidAtlantic Ridge), J. Geophys. Res., 106, 9411-9426.

Turner, J. S., and I. H. Campbell (1987), Temperature, density and buoyancy fluxes in "black smoker" plumes, and the criterion for buoyancy reversal, Earth Planet. Sci. Lett., 86, 85-92.

Tyler, P. A., and C. M. Young (2003), Dispersal at hydrothermal vents: A summary of recent progress, Hydrobiologia, 503, 9-19.
Van Dover, C. L., C. R. German, K. G. Speer, L. M. Parson, and R. C. Vrijenhoek (2002), Evolution and biogeography of deep-sea vent and seep invertebrates, Science, 295, 1253-1257.

Woods, A. W., and J. W. Bush (1999), Dimensions and dynamics of megaplumes, J. Geophys. Res., 104, 20,495-20,508.

E. T. Baker, Pacific Marine Environmental Laboratory, NOAA, 7600 Sand Point Way NE, Seattle, WA 98115, USA.

C. R. German, Woods Hole Oceanographic Institution, Clark South 276, Mail Stop 24, Woods Hole, MA 02543-1050, USA.

B. J. Murton and C. M. Sands, National Oceanography Centre Southampton, University of Southampton Waterfront Campus, European Way, Southampton SO14 3ZH, UK. (bjm@noc.soton.ac.uk) 